\title{
Impact of Implementation of Goods and Service Tax on Indian Banking Sector
}

\author{
Revathi R. ${ }^{1}$, Madhushree L. M. ${ }^{2}$, \& P. S. Aithal ${ }^{3}$ \\ ${ }^{1,2}$ Research Scholar, Srinivas Institute of Management Studies, Srinivas University, \\ Mangalore - India \\ ${ }^{3}$ Srinivas Institute of Management Studies, Srinivas University, Mangalore - India \\ E-mail: revathiradhakrishnan93@gmail.com
}

Type of the Paper: Research Case Study.

Type of Review: Peer Reviewed.

Indexed In: OpenAIRE.

DOI: https://doi.org/10.5281/zenodo.1404693.

Google Scholar Citation: IJCSBE

\section{How to Cite this Paper:}

Revathi, R., Madhushree, L. M. \& Aithal, P. S. (2018). Impact of Implementation of Goods and Service Tax on Indian Banking Sector. International Journal of Case Studies in Business, IT and Education (IJCSBE), 2(2), 18-32.

DOI: https://doi.org/10.5281/zenodo.1404693.

International Journal of Case Studies in Business, IT and Education (IJCSBE)

A Refereed International Journal of Srinivas University, India.

(C) With Authors.

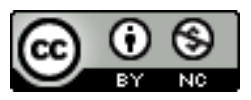

This work is licensed under a Creative Commons Attribution-Non Commercial 4.0 International License subject to proper citation to the publication source of the work.

Disclaimer: The scholarly papers as reviewed and published by the Srinivas Publications (S.P.), India are the views and opinions of their respective authors and are not the views or opinions of the S.P. The S.P. disclaims of any harm or loss caused due to the published content to any party. 


\title{
Impact of Implementation of Goods and Service Tax on Indian Banking Sector
}

\author{
Revathi R. ${ }^{1}$, Madhushree ${ }^{2}$, \& P. S. Aithal ${ }^{3}$ \\ ${ }^{1,2}$ Research Scholar, Srinivas Institute of Management Studies, Srinivas University, \\ Mangalore - India \\ ${ }^{3}$ Srinivas Institute of Management Studies, Srinivas University, Mangalore - India \\ E-mail: revathiradhakrishnan93@gmail.com
}

\begin{abstract}
The banking sector is one of the biggest and revenue generating sector in our economy. India is a country with impressively splendid banks with sufficient capital and well-regulated rules and regulations. One of the biggest transformations that the sector faced during this period is GST i.e., Goods and Service Tax, a new tax regime introduced in the midnight of 1 July 2017. Now the new tax regime has become one year old and there are so many changes which happened in the banking sector during this one-year periods. Introduction of GST to the banking sector was one the highly risky and challenging role for the government. GST is a replacement to the Value Added Tax (VAT) which was implied on goods and services. The main purpose of studying the impact of implementation of GST is to avoid double taxation on goods and services. It is a self-regulated tax system with a simplifies tax regime which reduces the multiplicity of tax. The purpose of this study is to know the challenges faced by the Banking sector and its effects on the customers after the implementation of the GST. New tax regime made an incredible step by the abolish of centralized registration of the banks. Now all the bank branches have to register under GST in each state for the smooth functioning. The tax rate has created an impression in the banking sector that the sector is contributing much toward the economic growth of the country. Tax slabs is another important and critical thing discussed in this paper which has substantially increased compared to the old tax regime. Data for the study have been collected from secondary data sources such as journals, internet, and news articles. Using the ABCD qualitative analysis technique, advantages, benefits, constraints, and disadvantages for both banks and the customers for payment of GST are identified.
\end{abstract}

Keywords: Banking sector, GST (Goods and Service tax), Cascading of tax, Simplified tax regime, Banking product and services.

\section{INTRODUCTION :}

The paper reflects on the impact of implementation of GST on the banking sector. It also put light on how the tax rates imposed on different products and services of banks and how it affects the customers.GST is playing a vital role in all sectors of the economy and the day to day life of the people. It has been discussed in newspapers from past one year about the changes in the price of the products and tax slabs of GST but still, people are in chaos. The introduction of GST (Goods and Service Tax) made a large change in the entire tax system of the country which is affected on 1121 items as from the newspaper source. GST is a replacement to the Value-added Tax (VAT) which was imposed on goods and services [1]. GST is an indirect tax which was introduced in India on July 1st of 2017 and was applicable throughout India which replaced multiple and compound taxes imposed by the central and state governments on a large number of goods and services. Under the GST tax system, goods and services are imposed with rates of $0 \%, 5 \%, 12 \%, 18 \%$ and $28 \%$. There is a unique rate of $0.25 \%$ on rough semi-precious and precious stones and also $3 \%$ of tax on gold. In addition to that, there is a cess of $22 \%$ or other rates on top of $28 \%$ GST applies on a few items like luxury cars, 
tobacco products, and aerated drinks. In the banking sector, it has made a huge change as almost all the products and services have a high tax rate compared to the previous one [1], [2], [5], [6]. An important advantage of GST is that it avoids the double taxation on goods and services.

Some of the advantages of GST are:

- Reduction in cascading of taxes

- Overall reduction in price

- Self-regulating tax system

- Non-intrusive electronic tax system

- Simplified tax regime

1. Reduction of cascading of taxes: There was a large number of taxes like services tax, customs duty, value added tax etc. imposed on goods and services traded in our economy. After the introduction of GST, there the cascading or overlapping of taxes in different sectors of the products from production to consumption has reduced. The tax for the good and services is paid equally to the state and the central government. in simple words, it is multiple taxes to a single integrated tax [3], [10].

2. An overall reduction in price: The prices of the goods are expected to reduce in the future due to the uniform tax imposed on different goods and services. the tax on each good and services are assigned or levied according to the different category in which the goods lies.

3. Self-regulated tax: GST facilitates the customers or the taxpayers to have an easy compliance and make their payment effortless.GST has introduced the concept of "Auto Notified", "Mismatch Mechanism" in order to find out any mismatches in the tax filing mechanism. The mismatch can happen from the side of the recipient and in such cases, the recipient himself can make a correction or the supplier can make mistakes like he /she didn't upload or pay tax on the invoice which he/she was issued. In these two cases, the recipient or supplier of the goods can do corrections in the tax filing [4], [5], [6].

4. Non-Intrusive electronic tax system: GST has been introduced as a non-intrusive tax system as it is bordered tax system and decreases the black money transaction and the free flow of goods and services.

5. Simplified tax regime: The tax system is more simplified, there is no cascading effect as each level of the transaction the tax has been set off.

6. Uniformity of tax system: There is uniform tax rates for various products in the market as the tax charged on various products are $0 \%, 5 \%, 12 \%, 18 \%$, and $28 \%$ depending on the value and of the category of the product.

\section{OBJECTIVES :}

- To study the responsibilities if Indian public sector banks registered for payment of GST.

- To know the issues faced by the banking sector after the implementation of GST.

- To know the tax rate imposed on products and services provided by the banks.

- The understand the challenges of the banks and the customers to fulfil GST norms.

\section{METHODOLOGY :}

Secondary data: The research paper is an attempt of research, based on the secondary data sourced from journals, Internet, articles, previous research paper which focused on the various aspects of goods and service activities. According to the requirements of the objectives of the study, the design is descriptive type. The accessible secondary data is used only for study [7].

\section{GST: TODAY'S BANKING :}

Banking sector is one of the oldest sectors which contributes a huge amount of wealth to the country. Now the earning of the sector has been increasing day by day. The banking system in India is divided into different sectors as shown in table 1.

Table 1: The number of banks in the country as on 2018

\begin{tabular}{|c|c|}
\hline Banks & Number of Banks \\
\hline Public sectors & 27 \\
\hline
\end{tabular}

Revathi R. et al. (2018); www.srinivaspublication.com 
International Journal of Case Studies in Business, IT and Education (IJCSBE), ISSN: 2581-6942, Vol. 2, No. 2, August 2018.

\begin{tabular}{|c|c|}
\hline Private & 22 \\
\hline Foreign Banks & 44 \\
\hline Regional rural banks & 56 \\
\hline Urban Cooperative banks & 1,589 \\
\hline Rural Cooperative banks & 93,550 \\
\hline
\end{tabular}

The above table shows the number of banks operates in the country in the year 2018. all the banks are registered under GST at each state and each branch they run in.

4.1 BANK WHICH ARE AUTHORISED IN CENTRE AND STATES FOR GST PAYMENT There are 26 public sector banks in the list (table 2) which are registered under GST for the for central and state level payment in India. All these banks which are mentioned above are registered under the GST for the smooth running of the business, transactions, and tax filing.

Table 2: It shows the name of banks which are registered under GST for any payment at central and state level

\begin{tabular}{|c|c|c|c|}
\hline \multicolumn{4}{|c|}{ Name of the Banks } \\
\hline Allahabad Bank & Dena Bank & United Bank of India & $\begin{array}{l}\text { State Bank of } \\
\text { Travancore }\end{array}$ \\
\hline Andhra Bank & Indian Bank & UCO Bank & IDBI Bank Ltd \\
\hline Bank of India & Indian Overseas Bank & Vijaya Bank & \\
\hline Bank of Baroda & $\begin{array}{c}\text { Oriental Bank Of } \\
\text { Commerce }\end{array}$ & State Bank of India & \\
\hline Bank of Maharashtra & Punjab National Bank & $\begin{array}{c}\text { State Bank of Bikaner } \\
\text { \& Jaipur }\end{array}$ & \\
\hline Canara Bank & Punjab \& Sind Bank & $\begin{array}{c}\text { State Bank of } \\
\text { Hyderabad }\end{array}$ & \\
\hline Central Bank of India & Syndicate Bank & State Bank of Mysore & \\
\hline Corporation Bank & Union Bank of India & State Bank of Patiala & \\
\hline
\end{tabular}

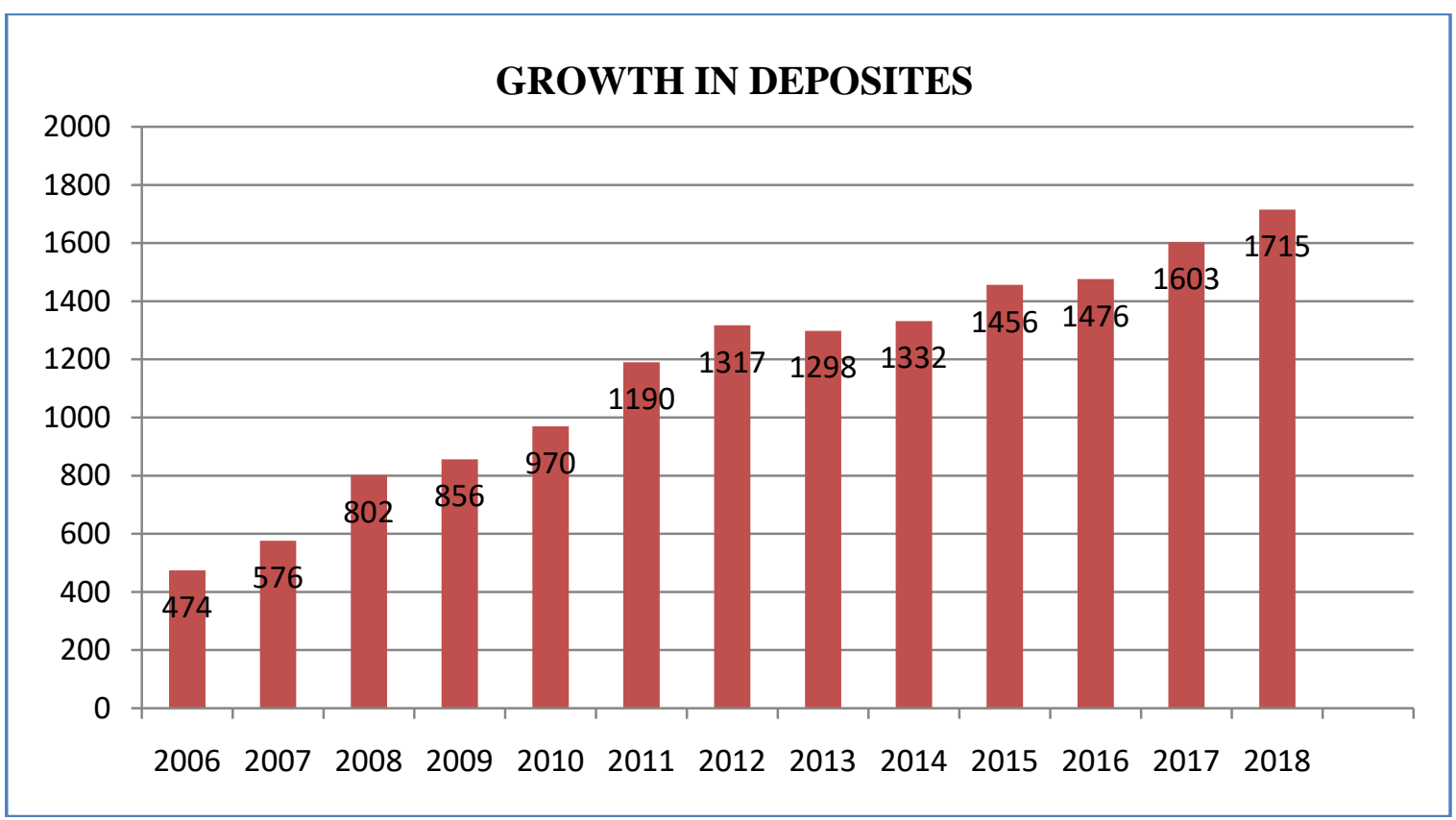

Fig. 1: Data on the growth of the deposits in the banking sector during past 12 years

In the above figure 1, there is a huge increase in deposits from the past 12 years. The $\mathrm{x}$-axis of the figure shows the amount in the US \$ billion and the y-axis shows the year-wise growth of the banking sector. As per the RBI, banking sector of India is effectively capitalized and well-regulated. The economic and financial conditions in the nation are far advanced to any other countries in the 
world. Market, credit, and liquidity risk studies advise that banks in India are generally flexible and have strongly faced the global economic crises. Indian banking industry has lately witnessed the rollout of innovative banking models, implementation of GST and the new tax rates which contributes more revenue to the sector [13], [14].

The impact of GST to the banking sector had made an impression that GST is doing an excellent job in the sector due to high rates compared to previous tax rates (service tax) but it has become a costly affair for customers. Most of the employees in the sector agree that GST is a good initiative taken by the government for sustainable banking but there is a high number of the problem arising about the new tax system and feels that GST to the banking sector is proved to be a cumbersome or complicated due to a large number of transactions. The banks were not allowed for a centralized registration under GST. They are required to do separate registration in each state they operate in [5], [6], [8].

\section{ISSUES IN THE BANKING SECTOR DUE TO THE ADVENT OF GST BASED ON THE OBSERVATION :}

\subsection{PROCEDURE OF REGISTRATION}

Before the advent of GST all the banks in India have a centralized registration under the Service tax law for all the branches in the country. The government has ruled out centralized registration for financial institutions called banks under the new tax regime goods and services tax and, it has mandated separate registration for each state they operate in. It has become a compulsory activity for all the bank which work within the country in order to carry out its functions. It created a huge compliance burden on the banks [8]. It requires high harmonization and control between the banks within and outside the state for tax matters. Under GST administration, accounting and financial records etc. are to be maintained separately for each state-wise. the banks doing state-wise registration, filing multiple returns for each state, multiple audit and assessments especially in a situation where banks have branches in almost every state and union territory of the county and with each state, each city, each locality has a branch of the bank [9].

\subsubsection{STEP IN THE REGISTRATION PROCESS:}

a. The customer has to Log on to www.gst.gov.in.

b. The customer has to get on the 'Services' tab on the list of options at the top of the page.

c. Three options will be provided, viz. 'Registration', 'Payments, and 'User Services'.

d. Got to the 'Registration' and select 'New Registration'.

e. It will be redirected to a fresh page in which the customer will have to select the option which differentiates whether he is a taxpayer or a GST practitioner prior to entering a few information such as the legal name of the business, the state and district in which the company is located, Permanent Account Number, email address and mobile number. This is fundamentally Part-A of the form.

f. The information of the customer has to be entered will have to be confirmed and verified by the portal, so the customer will receive a one-time password or an email for authentication.

g. Based on the type of business the customer is operating, he will be compulsory to upload a few documents as requested.

h. Part-B of the form will then have to be filled in with a small number of details after which the customer will obtain the Application Reference Number through email or SMS.

i. The customer's application will then be verified or checked by a GST officer and it could either be accepted or you will be requested to present some more information or documents until the authorities have all the required information to accept your application.

For each state separate registration has to be done, if a bank or trader has branches in numerous states. Businesses with more than 1 vertical can register individually for each of them. Banks have to register each and every branch in which they operate in. Any transactions or business activities are conducted only when the bank or the company is registered under GST [10], [15].

\subsection{INTER- STATE TRANSACTION BETWEEN TWO BRANCHES OF THE SAME BANK}

Before the implication of GST, the transaction between two branches of the same bank was not subject to any tax. But under GST tax regime interstate supply of goods and services or both between the same bank's two branches located in two states are taxable which is known as integrated goods 
and service tax (IGST). Generally, banks have a lot of common and shared services being supported by Head Office such as security software, call center etc. Further, many times one branch would internally provide service to other branches for example: resolving the issue of a customer having PAN India accounts, providing local information etc. to other branches etc [11]. If GST is to be charged on such supplies, even though the same is made without consideration, it would cause pointless hardship. But solution is provided in the valuation rules that in case of a transaction with distinct persons, value disclosed on the invoice shall be deemed to be taken as an open market value, however still valuation issues may creep as this rule does not apply if the receiving branch is not able to avail the full credit due to any reason whatsoever. Since, in a banking sector tracking such transactions would prove to be a cumbersome task and lead to multiple interpretations and disputes, therefore one suggestion is that by the virtue of Rule 6(7) of GST Valuation Rules, banking services be categorised in such class of services where value for any transactions undertaken between the distinct persons is deemed to be considered as Nil [12].

\subsection{PLACE OF SUPPLY BANKING SERVICES}

The place of supply of services under GST Law for banking and other financial services shall be the location of the recipient of services on the records of the supplier of services. Provided that if the place of the recipient of services is not on the records of the supplier, the place of supply shall be the place of the supplier of services. However, what constitutes the 'records of the supplier' is not defined in the law leading to multiple interpretations as to whether it is to be understood as accounting records or customer records, vendor records and so on [12], [13]. Further, in some cases banks would have multiple addresses of the same customer in its records, this is possible as in case of a banking sector a customer would add multiple accounts within the same customer id and in which case only one address of the customer under whose address that customer id is registered would be reflected as the address on records. However, it is possible that the transaction is undertaken with the account holder within the same customer id but having a branch in the different state. In such a situation, if strictly banks pay GST to the state based on the "address on record" then it may end up paying GST in a wrong state. Therefore, banks have to record the address of each account holders within the same customer id and GST needs to be charged on that account holder and accordingly, the tax also must be paid to that respective state government of the account holder and not the single address captured for the entire customer id [17].

\subsection{REVERSAL OF INPUT TAX CREDIT ON CAPITAL GOODS}

Before the implication of GST, as per Rule 6(3B) of CENVAT Credit Rules, 2004, an assessee in the banking sector has to reverse $50 \%$ of the CENVAT Credit taken on a monthly basis on input and input services [13]. However, banks can take full credit on Capital goods unless the said capital goods are exclusively used for any exempted service. Now under section 14 of the GST law states that banks engaged in supplying goods and services by way of accepting deposits, extending loans have to reverse $50 \%$ of the eligible input tax credit on inputs, capital goods, and input services. It is pertinent to note that requirement of reversal of standard $50 \%$ credit even on the capital goods portion will have a negative impact [14] Various office furniture, equipment, cash-counting machines, computers, printers, air-conditioners etc. are of high procurement cost for any branch of the bank and if $50 \%$ of the credit on the same is to be reversed then it shall have an adverse impact [15], [16].

\subsection{GST IS CHARGED ON ALL BANKING ACTIVITIES}

Banks have charged GST on various products and services carried on by the banks except for deposits, which can be classified like this:

\section{(1) TRANSACTION CHARGES:}

Transaction charge is something which we pay when we are in need of a quick cash and it is a tendency to run to the nearest ATM's available. The changes in the ATM's transaction charges, making multiple trips to withdraw cash or check balance will cost you more under the tax system GST. Transaction charges have been increased to $18 \%$ which was $15 \%$ earlier. The shocking news is that the ATM transactions are restricted to a certain point i.e., first 5 withdrawals are free after 5 withdrawals Rs.20 per withdrawal is charged in order to reduce the withdrawal of money through ATM's which will automatically increase the usage of internet banking. Also, the usage of chequebooks will be expensive if any customer uses more than 50 cheques a year and it is charged 
less than Rs.100. The individuals have to pay Rs.3 more for every Rs.100 paid for banking transactions [14], [16].

(2) LOANS:

As per information, it is said that all the loans are taxable under GST for $18 \%$ and there is no chance of tax percentage to go beyond the tax slab of $18 \%$. But there is a big concern about the home loans which was availed to the borrowers for a VAT of $5 \%$ for construction materials and $3.5 \%$ service tax, overall of 8.5 which is now available only as per the GST rate $18 \%$ which will be little more expensive for the borrowers [18]. And there is a chance of an increase in the interest rate added on home loans by the banks and lenders too.

(3) INVESTMENTS:

Investments like mutual funds are affected negatively due to the introduction of GST. GST bang on the income of mutual funds will certainly have an effect on the consumers. For an investment company, an expense ratio is a cost incurred by them to operate their mutual funds. The Goods and Service tax will be on the Total Expense Ratio of the mutual funds and has been increased by $3 \%$. In case of the policyholders, they have to pay high premiums amount on their insurance assuming, a family spend a sum of Rs 50,000 per annum on insurance exclusive of service tax, their expenses will be increased by 3\%, i.e., Rs 1500. Earning up to Rs 20 lakh will stay exempted from GST for mutual fund distributors [18], [19].

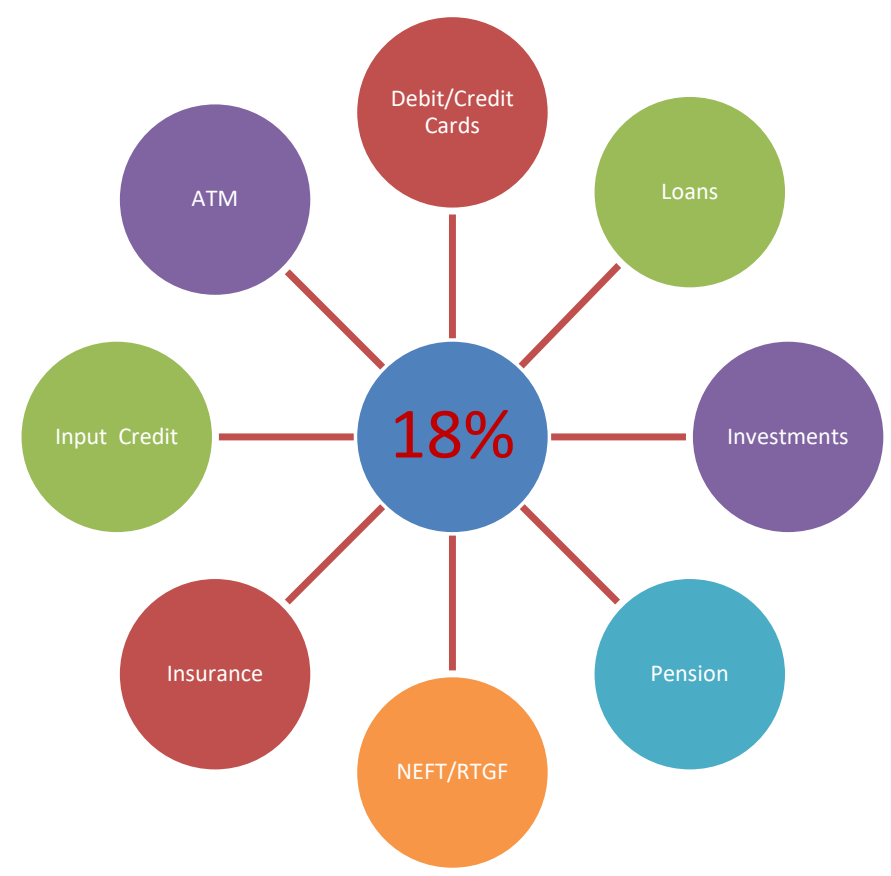

Fig. 2: The figure represents various products and services provided by banks which charge $18 \%$ GST replacing the $15 \%$ tax.

\section{(4) INSURANCE:}

GST has a severe effect on insurance as there is a rise in the premium, especially for life, health, and car insurance policies. The tax rate has increased from $15 \%$ to $18 \%$ under GST. For example, if the complete premium is for life insurance, a tax rate of $18 \%$ will affect the entire premium.

\section{(5) INPUT TAX CREDIT:}

Under GST, 50\% of the CENVAT credit availed against inputs, input services, and capital goods is to reverse which leaves them a position of reduced credit of $50 \%$ on capital goods thereby increasing the cost of capital. Input tax credit is covered under GST only when your supplier has deposited the tax he collected from you. It is to be matched and validate before claiming it. So, it is compulsory that all supplier must is registered under GST [22]. 


\section{(6) OTHER SERVICES:}

Banking facilities like locker facilities, tax payment, billing, and shopping etc. which are offered by the banking sector are taxable for $18 \%$ under GST which is $3 \%$ higher than the early tax rates. In case of forex $1 \%$ of the gross amount of the Indian rupee is charged under GST i.e., the dissimilarity in the selling rate and buying rate of rupee which is multiplied with the total units of currency. The pension is charged under salary even if it is service provided by the bank [13], [23].

\section{REVIEW OF BANKING TAX RATE IMPLIED ON THE PRODUCTS AND SERVICES UNDER GST :}

The table 3 shows a brief description of the products and services provided by bank and which help us to have a quick understanding of various tax rates imposed on various products and services.

Table 3: The various tax rates imposed on various products and services

\begin{tabular}{|c|c|c|c|}
\hline Items & Taxable & Not Taxable & Tax \% \\
\hline Deposits & - & NT & - \\
\hline Debit Card & $\mathrm{T}$ & - & $18 \%$ \\
\hline Credit Card & $\mathrm{T}$ & - & $18 \%$ \\
\hline Loan & $\mathrm{T}$ & - & $18 \%$ \\
\hline Forex & $\mathrm{T}$ & - & $1 \%$ of gross rupee \\
\hline Investments & $\mathrm{T}$ & - & $18 \%$ \\
\hline Banking facilities & $\mathrm{T}$ & - & $18 \%$ \\
\hline Pension & - & $\mathrm{NT}$ & - \\
\hline Remittance (NEFT, RTGS) & $\mathrm{T}$ & - & $18 \%$ \\
\hline Insurance & $\mathrm{T}$ & - & $18 \%$ \\
\hline ATM & $\mathrm{T}$ & - & $18 \%$ \\
\hline Input Credit Tax & $\mathrm{T}$ & - & $18 \%$ \\
\hline
\end{tabular}

\section{EXCEPTIONS IN GST :}

- As per GST Law 2017, there is no GST payable on Services received by the Reserve Bank of India from outside India in relation to the management of foreign exchange reserves. So, the rate of GST payable on Services received by the RBI from outside India in relation to the management of foreign exchange reserves is nil rate [8], [22].

- In the banking sector services by the way of extending loans or advances, deposits in so far as the consideration is represented by way of interest or discount (other than the interest in credit card services) [22].

- Services by the way of Inter sale or inter purchase of foreign currency among banks or authorized dealers of foreign exchange or between banks and such dealers.

- Services provided by a bank which is going to be acquired, to any individual in relation to the settlement of any amount of money up to two thousand rupees in a solitary transaction transacted through credit card, debit card or charge card or other payment card service [23], [24].

\section{IMPACT ON CUSTOMERS OF THE BANKS :}

Due to the arrival of GST, the tax rate on each and every products and service of the banks have become expensive and less affordable to the customers. In table 2, various tax rates on various items are explained.

1. Debit card and a Credit card is one of the common instruments used by the customers nowadays, the tax charged on these instruments is $18 \%$ which is costlier than the previous rate which was $15 \%$.

2. Loans were available at a cheaper rate before the advent of GST, now the rate has been fixed to $18 \%$ which made the customers in pressure and uncertainty that whether the customer will be able to repay the amount [22].

3. Investments like mutual funds are negatively affected by GST. the customers are in great strain that the cost incurred by the investments banks are very high and the tax charged on these 
investments is $18 \%$ which is very much higher for the customers to afford and mutual funds are largely based up to the total expense ratio which has gone up by 3\% after the initiation of GST [23]. 4. Banking facilities like locker facilities, tax payment, billing, and shopping etc. are widely used by the customer. It was charged at a rate of $15 \%$ and now it has changed to $18 \%$. Even though it is expensive customers with large assets always maintain a locker system for their safety purpose.

5. Increase in the premium caused a large number of the customer to withdraw the insurance policy. people with low income cannot afford the premium charged under GST.

\section{ABCD ANALYSIS ON GST IN BANKING SECTOR :}

ABCD framework can be used to analyze the individual characteristics, system characteristics, effectiveness of a concept or idea, effectiveness of a strategy while studying the business value in the society. ABCD analysis framework can be used for any kind of company case study. ABCD analysing framework allows the researcher to analyse any issues related to both internal and external to its business [20], [21]. This analysis framework being simple and straightforward, can be used to study many company issues or problems to find a suitable solution through simplifying the issues/problems by identifying the affecting factors through the factor analysis and critical constituent elements through elemental analysis [20]. Analysing business models, business systems, business strategy, business concepts and ideas, products \& services of a company, future expansion plans of a company etc. through ABCD constructs allows the readers to identify and understand the problems from various stakeholder's point of view so that an optimum solution can be developed. Thus, using $\mathrm{ABCD}$ analysis framework in suitable depth either qualitative listing, qualitative analysis, or quantitative analysis of identified issues is recommended in company case study as a research methodology [7], [21], [38 - 45]. SWOC analysis framework can be also used to know the strengths, weakness, opportunities, and challenges of GST in the banking sector [31-37].

Table 4: The table shows the advantages and benefits of GST in the banking sector and its customer [7], [20], [21].

\begin{tabular}{|l|l|}
\hline \multicolumn{1}{|c|}{ Advantage } & \multicolumn{1}{c|}{ Benefits } \\
\hline Self regulated tax system & Easy understandable for general public \\
\hline Transparent tax system & No confusion in tax filing and tax rate \\
\hline Uniform tax rate & No tax on deposit \\
\hline Compulsory registration under GST & Increased the number of online banking \\
\hline & $\begin{array}{l}\text { Registration under GST will reduce the amount } \\
\text { of tax payable on the purchase of goods }\end{array}$ \\
\hline
\end{tabular}

Table 5: The table shows the disadvantages and constrains of GST in the banking sector and its customer [7], [20], [21].

\begin{tabular}{|l|l|}
\hline \multicolumn{1}{|c|}{ Disadvantages } & \multicolumn{1}{c|}{ Constraints } \\
\hline $\begin{array}{l}\text { Tax has increased to } 18 \% \text { compared to the } \\
\text { earlier service tax of } 15 \%\end{array}$ & Banking became costlier to the customers \\
\hline $\begin{array}{l}\text { Loans are charged for } 18 \% \text { without any other } \\
\text { differentiation in the tax rate. }\end{array}$ & $\begin{array}{l}\text { Customers are charged 18\% on home loan, } \\
\text { before which was 8.5\%. }\end{array}$ \\
\hline Place of supply for banks are not specified & $\begin{array}{l}\text { In banking, place of supply of service shall be } \\
\text { the location of the customer on records. }\end{array}$ \\
\hline $\begin{array}{l}\text { Due to state- wise registration, multiple audit } \\
\text { and assessment is required }\end{array}$ & $\begin{array}{l}\text { Difficult for the bank to cope up with the } \\
\text { changes in registration as the presence of the } \\
\text { bank in each locality. }\end{array}$ \\
\hline $\begin{array}{l}\text { Interstate transaction between branch of the } \\
\text { same bank is charged. }\end{array}$ & $\begin{array}{l}\text { It is expensive and inconvenient task for the } \\
\text { banks that each transaction between branches } \\
\text { of the same banks are attracted by IGST. }\end{array}$ \\
\hline
\end{tabular}



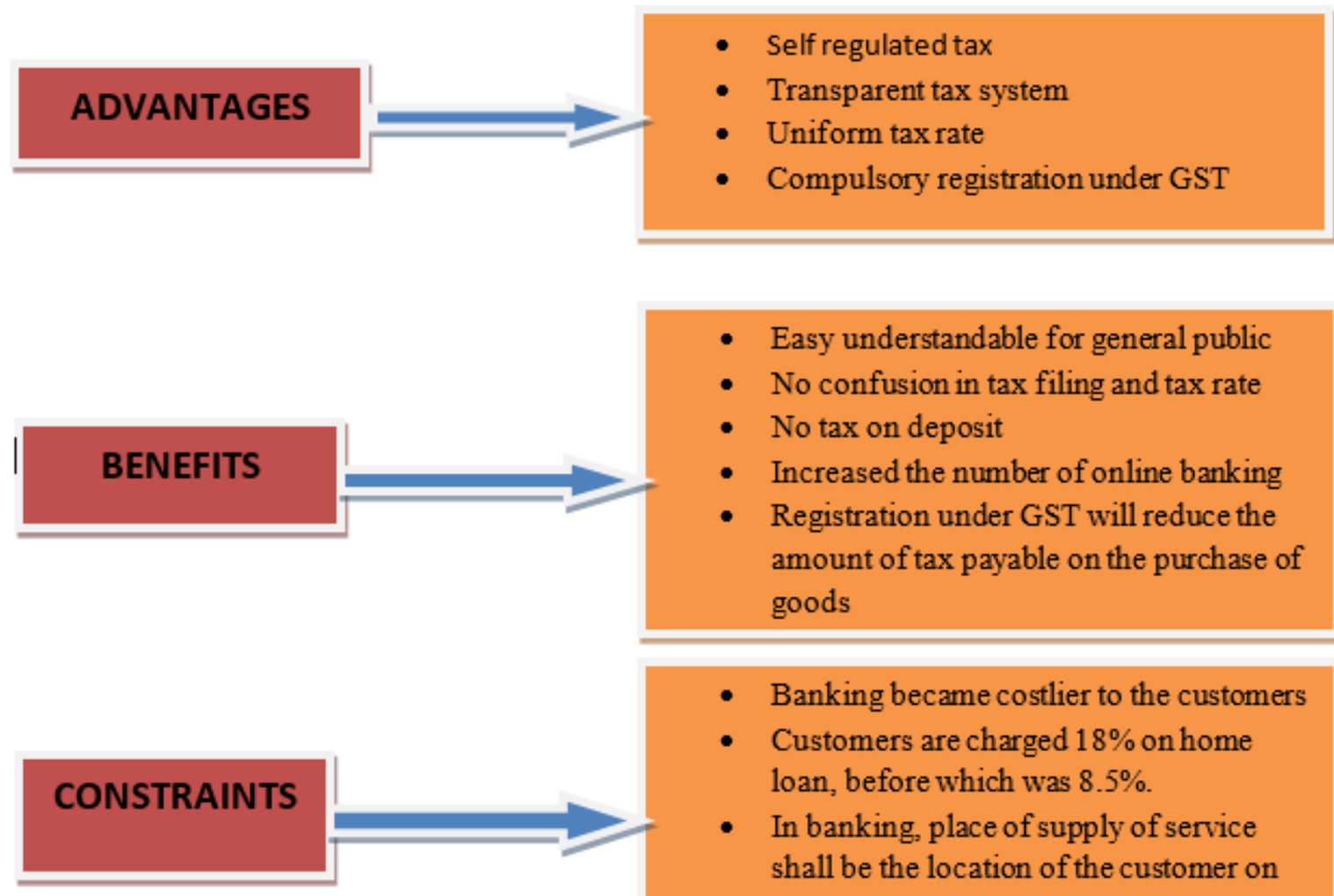

- Banking became costlier to the customers

- Customers are charged $18 \%$ on home loan, before which was $8.5 \%$.

- In banking, place of supply of service shall be the location of the customer on records.

- Difficult for the bank to cope up with the changes in registration as the presence of the bank in each locality.

- It is expensive and inconvenient task for the banks that each transaction between branches of the same banks are attracted

- Tax has increased to $18 \%$ compared to the earlier service tax of $15 \%$

- Place of supply is not specified.

- Loans are charged for $18 \%$ without any other differentiation in the tax rate.

\section{DISADVANTAGES}

Fig. 3: The figure describes about the advantages, benefits, constraints and disadvantages in the banking sector due to the introduction of GST.

\section{Advantages}

- Self-regulating tax system: GST has introduced the concept of "Auto Notified" and "Mismatch" mechanism so it is known as a self-regulating tax system in which the mismatch shall be 
automatically notified by the system to both the supplier/bank and recipient/customer and also auto-check provisions are made to identify fraudulent practices [22].

- Transparent tax system: Consumers will get to know the actual amount of taxes they are paying for goods and services in the form of a single GST rate that which is split between central and state governments [27].

- Uniform tax rate: In the banking sector, GST maintains a uniform tax rate of $18 \%$ i.e., all the services are taxed for $18 \%$ in the banking sector.

- Compulsory registration: Under GST compulsory registration for the banks in each branch they operate in order to reduce the confusion in the tax mechanism in each state and each branch for any transaction [23], [29].

\section{Benefits}

- Easy understandable for the general public: GST is a new tax regiment involved with a large number of goods and service. it is a simplified way of tax in order to build the people aware of how the goods and services are taxed. The tax is charged on different commodity under different slabs of $0 \%, 5 \%, 12 \%$ and $18 \%$ which easy for the people to remember and understand.

- No confusion in filing tax and tax rates: The people who have to pay GST does not have any confusion in the tax rate as it is a uniform tax rate. there is uniform tax rate of $0 \%, 5 \%, 12 \%, 18 \%$ and $28 \%$ [23], [26].

- No tax on deposits: The bank is not charging any GST on deposits made by the customers. It is totally exempted from GST due to that there is a huge increase in the deposits of the bank.

- Increased number of Online banking: Under ATM withdrawal the first 5 withdrawals are free after 5 withdrawals Rs.20 per withdrawal is charged in order to reduce the withdrawal of money through ATM's which will automatically increase the usage of internet banking.

- Registration under GST: It will make the entire tax collection easier and each branch of the bank can have an independent tax filing system [24], [25].

\section{Constraints}

- Banking became costlier for the customer: One of the important constraints of the banking sector is due to the increase of the tax rate in almost all the products and services, it became a costlier activity for the customer as it became $18 \%$ [24]

- Home Loans: GST has affected mainly on the home loan. now all the products and services offered by the bank is $18 \%$ which was earlier $15 \%$ except home loan which was $8.5 \%$. There is a huge increase of $9.5 \%$ tax on home loan due to GST.

- Place of supply: Under GST, the place of supply of services for banking and other financial services shall be the location of the recipient of services on the records of the supplier of services. Provided that if the location of the recipient of services is not on the records of the supplier, the place of supply shall be the location of the supplier of services. the place is not specified in the GST law for banking activities which creates a huge confusion [25], [30].

- Registration process: Each branch of the same bank should register separately under GST, it forces the bank to do multiple audit and assessments.

- Expensive and attracts IGST: It is an expensive and inconvenient task for the banks that each transaction between branches of the same banks are attracted to IGST. the transaction between each branch of same banks in different states is taxed under GST. It causes inconvenient for the banks located in different states [26], [27].

\section{Disadvantages}

- The tax rate has increased to $18 \%$ : The services tax which was provided in our country was $15 \%$ earlier which is now increased to $18 \%$. All the products and services offered by the banks are under $18 \%$ which has made banking services more expensive [28].

- Place of supply: One of the drawbacks of GST law is that the place of supply is not specified for the banking activities. the banks have to assume the customer's contact point as the place of supply of services [30].

- Home loan: Compared to other loans home loan have higher rates than another loan, the customer is in shock due to the huge increase in the home loan. 
- Registration: One bank has to register multiple times in all branches at a different state. it became a hectic work for the bank when GST was introduced at first [29], [30].

- Interstate charges: GST is charged IGST, CGST and SGST for the banking transaction for each state and interstate transaction are charges IGST for every bank.

\section{FINDING AND SUGGESTIONS :}

(1) All the banks in India are registered under GST at each state, each branch. The transaction is done through the GST act. The banks have to file multiple returns state-wise, numerous audits and assessments; particularly in a situation where banks have the existence in about all state and union territory of the country and there are large number banks located in each city and locality in the state. With loads of braches, the entire harmonization and integration of each state regional bank shall also be a challenge. Therefore, the government must bring in some unique proposal to the banking sector so that the high administration and compliance trouble which is placed under the GST is reduced as the business activities of banking sector entirely differs from that of other sectors.

(2) The transaction between two branches of the same bank located at two different states is taxable under GST which is called integrated goods and service tax (IGST). When there are so many transactions from the different branches of the same bank it will be difficult for the banks to track the transaction and the transaction will be cumbersome. One of the relaxations is the valuation under GST rule that the banking services be categorized in such a way that value for any transaction undertaken between a distinct person is deemed to be considered as Nil.

(3) Under GST the supply of service is defined in the address of the customer provided in the record which has submitted at the time of opening an account. The point of contact of the customer will be defined as the record which is already entered in the database of the bank. It is a huge task of the banks to find out the customer address or the account holder's address of each account holder within the same customer identification and GST is charged on the person and the tax was paid to the particular state government of the customer or the account holder.

(4) GST has made a uniformity in the entire good and service tax in our country, but the tax imposed on various products and services of the banks are much higher than earlier. if comes to a conclusion that banking services and products were costlier before.

(5) From the above study, the most disappointing thing for the customer is an increase in the tax rate of the home loan which was much lower compared to the current tax regime. the products and services of the banks are charged with a uniform tax rate of $18 \%$. I would like to suggest that if the bank can reduce the rate of charges in some of the services provided by them then there will be huge customer satisfaction. they may be an increase in the banking activities.

(6) Under GST the deposits in banks are exempted from tax, as a result, there is a huge increase in the number of accounts holding or deposits in the banking sector. (Fig 1) 7.

(7) Even though it has been implemented from past 12 months, till the taxpayer and other common people have a doubt regarding the tax rates, items charged under GST and, how much of tax should be paid. So, in order to make a sense about what is GST to the customer, the concerned bank should provide brochures to the customer to understand various tax imposed on various products and services to the customer who is holding an account in the bank.

\section{CONCLUSION :}

The upshot of the study concludes that GST is a risky and challenging initiative taken by the government for sustainable banking and a uniform tax is imposed on all the products and services. the issues faced by the banking sector a highlighted in this paper in order to understand how challenging the implementation of GST in the banking sector was. The banks have to register in each state they operate in. All the services are provided with the same tax rate of $18 \%$ except deposits which is exempted from tax and services like ATM withdrawals, input tax credit, cheque, loans, investments have a negative impact after the implementation of GST which made all these services very expensive to the customer, but it generates a large amount to the Indian banking sector. And also, it is said that Rs. 3 more for every Rs.100 paid for banking transaction which contributes a huge amount to the economy. The transaction between two branches of the same bank was not subject to any tax. but under GST tax regime interstate supply of goods and services or both between the same 
bank's two branches located in two states are taxable which is known as integrated goods and service tax. Under GST Law for banking and other financial services shall be the location of the recipient of services on the records of the supplier of services. GST law states that banks engaged in supplying goods and services by way of accepting deposits, extending loans must reverse $50 \%$ of the eligible input tax credit on inputs, capital goods, and input services. The banking sector has now settled with the current tax rates and adopted the changes and runs smoothly.

\section{REFERENCES :}

[1] Madhushree, M., Raghuram, Daroji. (2017). GST- Great Scheme for Transformation- Impact of GST on Indian Tax Structure, Pay India -2017 Emerging tax Reform and its Implication, 1-4.

[2] Vasanthagopal. (2011). GST in India : A Big Leap in the Indirect Taxation System. International Journal of Trade, Economics and Finance, 2(2), 1-3.

[3] Garg, G. (2014). Basic concepts and features of good and service tax in India. International Journal of scientific research and Management, 2(2), 542-549.

[4] Khurana, A., Sharma, A. (2016). Goods and Services Tax in India-A Positive Reform for Indirect Tax System. International Journal of Advanced Research, 4(3), 500-505.

[5] Shilpa, K., Farzana., Shruthi. (2017). GST Implementation and Its Implication, Pay India -2017 Emerging tax Reform and its Implication, 44-46.

[6] Oates, W. E. (1969). The effects of property taxes and local public spending on property values: An empirical study of tax capitalization and the Tiebout hypothesis. Journal of political economy, 77(6), 957-971.

[7] Aithal, P. S. (2017). ABCD Analysis as Research Methodology in Company Case Studies. International Journal of Management, Technology, and Social Sciences (IJMTS), 2(2), 40-54. DOI: http://dx.doi.org/10.5281/zenodo.891621.

[8] Mujalde, S., Vani, A. (2017). Goods and Service Tax (GST) and its outcome in India. Journal of Madhya Pradesh Economic Association, 27(1), 1-4.

[9] Palil, M. R., Ibrahim, M. A. (2011). The impacts of goods and services tax (GST) on middle income earners in Malaysia. World Review of Business Research, 1(3), 192-206.

[10] Anbuthambi, B., \& Chandrasekaran, N. (2017). Goods and Services Tax (GST) and training for its implementation in India: a perspective. ICTACT journal on management studies, 3, 511-514.

[11] Bird Richard M. (2012). The GST/HST: Creating an integrated Sales Tax in a Federal Country. The School of Public Policy, SPP Research Papers, 5(12), 1-38.

[12] Shokeen, S., Banwari, V., Singh, P. (2017). Impact of goods and services tax bill on the Indian economy. Indian Journal of Finance, 11(7), 65-78.

[13] Garg, Girish (2014). Basic Concepts and Features of Good and Services Tax in India. International Journal of scientific research and Management, 2(2), 542-549.

[14] Indirect Taxes Committee, Institute of Chartered Accountants of India (ICAI) Goods and Services Tax (GST). 2015. Retrieved from: http://idtc.icai.org/download/Final-PPT-onGSTICAI.pdf.

[16] Kundu, N., \& Chakraborty, A. (2017). Dependence on Ecosystem Goods and Services: A Case Study on East Kolkata Wetlands, West Bengal, India. Wetland Science, 381-405. Springer, New Delhi.

[17] Tewari, V. K. (2018). Goods and Service Tax. GST Simplified Tax System: Challenges and Remedies, 1(1), 173-176.

[18] Yadav, S. S., Shankar, R. (2018). Goods and service tax (GST): how and why. Journal of Advances in Management Research, 15(1), 2-3. 
[19] Banerjee, S., Agrawal, P. (2018). Impact of Goods and Service Tax after Implementation. Global Journal of Management and Business Research, 18(2), 1-6.

[20] Aithal, P. S. (2017). An Effective Method of Developing Business Case Studies Based on Company Analysis. International Journal of Engineering Research and Modern Education (IJERME),2(1), 16-27. DOI: http://dx.doi.org/10.5281/zenodo.400579.

[21] Aithal, P. S. \& Suresh Kumar, P. M. (2016). Theory A for Optimizing Human Productivity, IRA International Journal of Management \& Social Sciences, 4(3), 526-535. DOI :http://dx.doi.org/10.21013/jmss.v4.n3.p2.

[22] Milandeep, Kour., Kajal, Chaudhary., Surjan, Singh., Balijinder, Kaur (2016). A study of impact of GST after its implementation. International journal of innovative studies in sociology and humanities,1(2), 17-24.

[23] Bedi, Balwinder., Kavish, Sharma (2017). Moving to goods and service tax in India: Impact on India's growth. International Journal of Engineering Research \& Management Technology, 4(3), 120-128.

[24] Kumar, M., \& Kumar, C. Y. (2017). GST \& its Probable Impact on the FMCG Industry in India. International Journal of Research in Finance and Marketing, 7(4), 183-193.

[25] Sunitha, G., \&Sathischandra, P. (2017). Goods and Services Tax (GST): As a new path in Tax reforms in Indian economy. International Journal of Research in Finance and Marketing, 7(3), 55-66.

[26] Sehrawat, M., Dhanda, U. (2015). GST in India: A key tax reform. International journal of research granthaalayah, 3(12), 133-141.

[27] Parashar, N., Joshi, D., \& Chopra, P. K. (2017). Exploring the influence of transition to GST on consumer behaviour related to FMCG in India. Int. Journal of Management and Development Studies, 6(4), 50-57.

[28] Ansari, K., \& Jain, G. (2017). Impact of GST on Indian start-ups. International Education and Research Journal, 3(5), 445-448.

[29] Dixit, P. (2018). Impact of GST In Indian Scenario. GST Simplified Tax System: Challenges and Remedies, 1(1), 245-249.

[30] Bodnar, G. (2018). Study of the tax management problem. Technology audit and production reserves, 3(5 (41)), 30-35.

[31] Madhushree, Revathi, R., Anil Kumar, Aithal, P.S. (2018). Business Strategies of Top Indian IT Company: Mindtree. International Journal of Case Studies in Business IT and Education (IJCSBE), 2(1), 22-36. DOI: http:// dx.doi.org/10.5281/zenedo.1249871.

[32] Aithal, P. S. and Suresh Kumar, P. M. (2015). Applying SWOC Analysis to an Institution of Higher Education. International Journal of Management, IT and Engineering (IJMIE), 5(7), 231-247. DOI: http://doi.org/10.5281/zenodo.163425.

[33] Jithin Raj, K. \& Krishna Prasad, K. (2018). A Critical Study on Business Strategies of 3i Infotech Ltd. International Journal of Case Studies in Business, IT and Education (IJCSBE), 2(1), 13-21. DOI: http://dx.doi.org/10.5281/zenodo.1247319.

[34] Sneha, M. S. \& Krishna Prasad, K. (2018). Analysis of Business Strategies of Salesforce.com Inc. International Journal of Case Studies in Business, IT and Education (IJCSBE), 2(1), 37-44. DOI: http://dx.doi.org/10.5281/zenodo.1252028.

[35] Sudharshan Prabhu, S. \&Vaikunth Pai T. (2018). A Study on Products and Services of HCL Technologies. International Journal of Case Studies in Business, IT and Education (IJCSBE), 2(1), 45-53. DOI: http://dx.doi.org/10.5281/zenodo.1253722. 
[36] Revathi, R., Madhushree, \&Aithal, P. S. (2018). Business Strategy of Top Indian Company: L\&T InfoTech. International Journal of Case Studies in Business, IT and Education (IJCSBE), 2(1), 64-89. DOI: http://dx.doi.org/10.5281/zenodo.1302770.

[37] Harshith Kumar, M., Krishna Prasad, K., \&Bhat, Subramanya. (2018). Accenture-Understanding Sustainable Business Strategies. International Journal of Case Studies in Business, IT and Education (IJCSBE), 2(1), 54-63. DOI: http://dx.doi.org/10.5281/zenodo.1254137.

[38] Aithal, P. S., V.T. Shailashree, \& Suresh Kumar, P. M. (April 2015). A New ABCD Technique to Analyze Business Models \& Concepts. International Journal of Management, IT and Engineering (IJMIE), 5(4), 409 - 423. DOI :http://doi.org/10.5281/zenodo.61652.

[39] Aithal, P. S. (2016). Study on ABCD Analysis Technique for Business Models, Business strategies, Operating Concepts \& Business Systems. International Journal in Management and Social Science, 4(1), 98-115. DOI :http://doi.org/10.5281/zenodo.161137.

[40] ShubhrajyotsnaAithal, \&Aithal, P. S., (2016), ABCD analysis of Dye doped Polymers for Photonic Applications. IRA-International Journal of Applied Sciences, 4(3), 358-378. DOI: http://dx.doi.org/10.21013/jas.v4.n3.p1.

[41] Architha Aithal, and Aithal, P. S., (2017). ABCD Analysis of Task Shifting - An optimum Alternative Solution to Professional Healthcare Personnel Shortage. International Journal of Health Sciences and Pharmacy (IJHSP), 1(2), 36-51. DOI: http://dx.doi.org/10.5281/zenodo.1038975.

[42] Aithal, P. S., (2017). ABCD Analysis as Research Methodology in Company Case Studies. International Journal of Management, Technology, and Social Sciences (IJMTS), 2(2), 40-54. DOI: http://dx.doi.org/10.5281/zenodo.891621.

[43] Aithal, P. S. (2017). Factor Analysis based on ABCD Framework on Recently Announced New Research Indices. International Journal of Management, Technology, and Social Sciences (IJMTS), 1(1), 82-94. DOI: http://dx.doi.org/10.5281/zenodo.584105.

[44] Aithal, P. S. (2017). ABCD Analysis of Recently Announced New Research Indices. International Journal of Management, Technology, and Social Sciences (IJMTS), 2(1), 65-76. DOI: http://doi.org/10.5281/zenodo.583644.

[45] Varun Shenoy, \& Aithal P. S., (2016). ABCD Analysis of On-line Campus Placement Model, IRA-International Journal of Management \& Social Sciences, 5(2), 227-244. DOI: http://dx.doi.org/10.21013/jmss.v5.n2.p3. 